\begin{tabular}{|l|c|c|c|}
\hline Eiszeitalter und Gegenwart & $\mathbf{5 5}$ & $\begin{array}{c}149-173 \\
4 \text { Abb., 5 Tab. }\end{array}$ & Hannover 2005 \\
\hline
\end{tabular}

\title{
Loess paleosol-sequences along a climatic gradient in Northern Iran
}

\author{
Martin Kehl, Reza Sarvati, Hassan Ahmadi, Manfred Frechen \& Armin Skowronek*)
}

Keywords: loess, paleosol, luminescence, past climate change, Pleistocene, Iran

\begin{abstract}
In Northern Iran, loess is found in different geomorphological settings along a climatic gradient ranging from subhumid to semiarid conditions. Loess-paleosol sequences were investigated in detail in three key sections located on the northern foothills of Alborz mountains (sections at Neka and at Now Deh) and in the loess hills north of Gonbad-e Kavus (section at Agh Band).
\end{abstract}

At the section at Neka, two pedocomplexes consisting of moderately to strongly developed Bwk, Bt or $\mathrm{AhBt}$ horizons are intercalated in fine textured loess. Luminescence age estimates indicate that the upper paleosol was formed during OIS 5a or 5c, whereas the lower pedocomplex might represent OIS 5e or older interglacial periods.

Nine light or dark brown paleosols (CBk, Bwk and Btk horizons) are intercalated in the loess at the section at Now Deh indicating different weathering intensities most likely during interglacial and interstadials periods of the Middle and Upper Pleistocene. The upper Bt horizon of Now Deh likely correlates with OIS 5e. The lower Bt horizons join to form a strong pedocomplex possibly correlating with OIS

\footnotetext{
* Anschrift der Verfasser: Dr. M. Kehl und Prof. Dr. A. Skowronek, INRES-Soil Sciences, University of Bonn, Nußallee 13, 53115 Bonn, Germany, Email: mkehl@uni-bonn.de, Prof. Dr. R. SARvati, Department of Geography, Shahid Beheshti University, Tehran, Iran, Prof. Dr. H. Ahmadi, College of Natural Resources, University of Tehran, Karaj, Iran, Prof. Dr. M. Frechen, Leibniz Institute for Applied Geosciences (GGA-Institut), Geochronology and Isotope Hydrology, Stilleweg 2, 30655 Hannover, Germany
}

7 or older interglacials. The pedocomplexes at Neka and Now Deh indicate polycyclic soil genesis including soil formation, truncation of the upper soil horizons, loess deposition and again soil formation.

In the loess hills near Agh Band, 40 m thick homogenous loess covers a brown paleosol $(\mathrm{Bw}(\mathrm{t}))$, possibly correlating with the last interglacial soil. The loess at Agh Band section has a high percentage of fine sand and coarse silt and contains significant amounts of gypsum.

The loess-paleosol sequences indicate pronounced climate changes from dry and cool to moist and warm conditions with loess deposition and soil formation, respectively. They are excellent terrestrial archives of Quaternary climate and environment change in Northern Iran.

\section{[Löss-Paläobodensequenzen entlang eines Kli- magradienten in Nordiran]}

\section{Zusammenfassung}

Im südlichen Kaspischen Tiefland und seinen umliegenden Gebieten treten Lösse in verschiedenen geomorphologischen Positionen entlang eines rezenten Klimagradienten von subhumiden zu semiariden Verhältnissen auf. Drei LössPaläobodenabfolgen werden beschrieben, die im nördlichen Vorgebirge des Alborz (Profile Neka und Now Deh) und im Lösshügelland nördlich Gondbad-e Kavus (Profil Agh Band) aufgeschlossen sind.

Das Profil Neka besteht aus feinkörnigem Löss, der von zwei kräftig entwickelten Paläobodenkomplexen aus Bwk-, Bt- und AhBt-Horizon- 
ten durchzogen wird. Erste Lumineszenzdatierungen weisen darauf hin, dass der obere Pedokomplex während der Sauerstoff-IsotopenStadien (OIS) 5a und/oder 5c gebildet wurde, während der untere das OIS 5e oder ein älteres Interglazial repräsentieren könnte.

Neun hell braune oder dunkel braune bis rötlich-braune Paläoböden (CBk-, Bwk- und BtHorizonte) des Lösses bei Now Deh spiegeln unterschiedliche Verwitterungsintensitäten von Interglazialen und Interstadialen des Mittleren bis Oberen Pleistozäns wider. Während der obere Bt-Horizont von Now Deh wahrscheinlich mit dem OIS 5e korreliert, bilden die unteren Bt-Horizonte einen Pedokomplex, der das Interglazial des OIS 7 repräsentiert. Die Pedokomplexe in Neka und Now Deh weisen jeweils auf polyzyklische Bodenentwicklung hin, die Bodenbildung, Bodenabtrag, Lössaufwehung und erneute Bodenbildung umfasste.

In den Lösshügeln bei Agh Band bedeckt ein 40 $\mathrm{m}$ mächtiges, weitgehend homogenes, gipshaltiges und feinsand- sowie grobschluffreiches Lösspaket einen braunen Paläoboden $(B w(t))$, der vermutlich in das letzte Interglazial zu stellen ist.

Die beschriebenen Löss-Paläobodenabfolgen dokumentieren den mehrfachen Wechsel von trocken-kalten zu feucht-warmen Klimaverhältnissen mit Lössablagerung bzw. Bodenbildung. Sie stellen ausgezeichnete terrestrische Archive des quartären Klima- und Umweltwandels Nordirans dar.

\section{Introduction}

In Northern Iran, loess is found in hilly areas along the rivers Aras in East Azerbaijan province (Fig. 1), bordering the Gorgan and Atrek rivers in Golestan province and west of the Hari river in Khorassan province (Busche, Grunert \& Sarvati 1990). Loess also covers the north- ern foothills of the Alborz mountains between Sari and Minoodasht (National Iranian Oil Company 1978; Geological Survey and Mineral Exploration of Iran) and locally occurs, for instance, on fluvial terraces of Sefid-Rud and Chalus River (National Iranian Oil Company 1978; Ehlers 1971; Paluska \& Degens 1980) or in the Gharatikan watershed (Okhravi \& Amini, 2001). Though Tietze (1877), Stahl (1923) and Bовек (1937) already mentioned loess deposits in Northern Iran, little information about the nature, origin and chronology of the loess has ever been published.

BARbier (1960) gave a short description of loess in the Sefid-Rud valley and correlated these deposits with the Holocene. Following this view, Ehlers (1971) suggested that brown paleosol horizons intercalated in the loess from Sefid Rud and also in loess deposits near Neka formed during moist periods of the Holocene, whereas loess deposition took place during dry periods. Lateef (1988) described loess deposits with intercalated brown paleosols near Now Deh, which are likely identical to the "folded loess" described by Rieben (1966). Lateef (1988) supposed that the brown paleosols represent the last interglacial period and that loess deposition took place during glacial times. Paleosols as markers of interglacial periods have widely been used in the pedostratigraphical correlation of loess-paleosol sequences with the global climatic record (e.g., BRONGER, 2002). Soil formation requires moist and warm climatic conditions during interglacial or interstadial times. A vegetation cover is needed to supply organic matter for accumulation of soil humus and to protect the soil against erosion. In contrast, the deposition of loess took place during periods of low temperature and increased aridity, when production of silt-sized grains was intensified by frost-shattering and glacial activity (e.g., WRIGHT 2001). Mainly silt-sized sediments were deflated from the flood plains 
and accumulated again by trapping through shrub or grass vegetation. In Southern Iran, loess and loess-like sediments were deposited in the Basin of Persepolis located in the Southern Zagros mountains. There, the loess formation pathway is explained by intensified production of silt-sized material during the Last Glacial maximum, fluvial transport to the alluvial plains, deflation, aeolian deposition and fluvial displacement (KeHL et al. 2005).

Cyclical climate changes like those of the Quaternary can result in the formation of stacked loess-paleosol sequences as observed in the study area. The grey, brown, reddish-brown or mottled paleosol horizons of loess-paleosol sequences likely correlate with different weathering intensities depending on temperature and precipitation during the period of formation (e.g., Bronger, Winter \& Heinkele 1998). Furthermore, several other physical properties of loess-paleosol sequences are suitable as indirect proxy measures of past climate. These so-called climate proxies include grain size, colour, mineral assemblages, the content of organic carbon, $\mathrm{CaCO}_{3}$ or iron fractions, micromorphological features, major and trace element composition, isotope signatures or magnetic susceptibility (e.g., Tungsheng et al. 1985; Bronger \& Heinkele 1989; Bronger, Winter \& Sedov 1998; Derbyshire, Kemp \& Meng 1997; Hatté et al. 2001; Ding et al. 2002). Furthermore, biological indicators like pollen or mollusc assemblages proved very useful as climate proxies (e.g., Krolopp \& SüMEGI 1995).

Absolute age determinations are required to correlate loess deposits with those from different areas and with the global marine or ice core record (oxygen isotope stages, OIS) in order to study the impact of climatic changes on the terrestrial environments in a transect from west to east, from more oceanic to more continental driven climate. Several methods for relative and absolute age assessments of loess deposits are available including radiocarbon, luminescence dating, amino acid racemisation and paleomagnetic measurements. The infrared optically stimulated luminescence method (IRSL) has been shown to be highly suitable for the dating of loess in Tajikistan and to determine loess mass accumulation rates in Europe (FrECHEN \& Dodonov 1998; Frechen, Oches \& KoHFELD 2003).

In this paper we give first detailed descriptions of three key sections of Northern Iranian loess and its paleosols. From these sequences eight samples were taken for a first luminescence dating approach to investigate the suitability of loess from Northern Iran and to set up a more reliable chronological framework. The high potential of Iranian loess as terrestrial archives of climate and environment change is indicated.

\section{Materials and methods}

\subsection{The study area}

The loess-paleosol sequences are located at Neka and Now Deh on the northern foothills of the Alborz mountains east of Sari and east of Gorgan, respectively, and at Agh Band in the loess hills north of the city of Gonbad-e Kavus (Fig. 1). The loess hills near Agh Band are part of the so-called Iranian loess plateau. The coordinates and altitudes of the sections of interest are given in table 1.

Modern mean annual precipitation ranges from $-750 \mathrm{~mm} / \mathrm{a}$ to $-350 \mathrm{~mm} / \mathrm{a}$ in the vicinity of the sections at Neka and Agh Band, respectively. This gradient reflects the decline in precipitation from west to east along the southern coast of the Caspian Sea. In addition, rainfall also decreases from south to north with increasing distance from the Alborz mountains as indicated in annual mean rainfall data of Now Deh and Agh Band. Mean annual temperatures are about $17^{\circ} \mathrm{C}$ (Tab. 1). The wind regime of 
Northern Iran is mainly driven by pressure differences between the Caspian Sea basin and the Central Iranian Highlands. During summer a strong heat depression forms over hot Central Iran resulting in north-westerly to north-easterly air-mass flows from the cooler Caspian Sea basin and from the Turkmen steppe. In winter, winds can blow in the opposite directions from the high-pressure area over cold Central Iran towards the low-pressure over the comparatively warm Caspian Sea. Strong foehn type winds called "garmsil" can occur on the northern faces of Alborz and Kopet Dagh mountains, which might transport large quantities of dust and sand towards the Turkmen deserts (MIDDLETON 1986).

With the southward shift of the paleo-Monsoon during the Last Glacial Maximum (LGM, Sirocko et al. 1991) it might be assumed that paleowind directions in Iran at that time were also dominated by north-westerly to northeasterly equatorial currents. However, ThOMAs et al. (1997) gave evidence for south-eastern wind directions in the Central Iranian Highlands during the LGM.

Little detailed information has been published

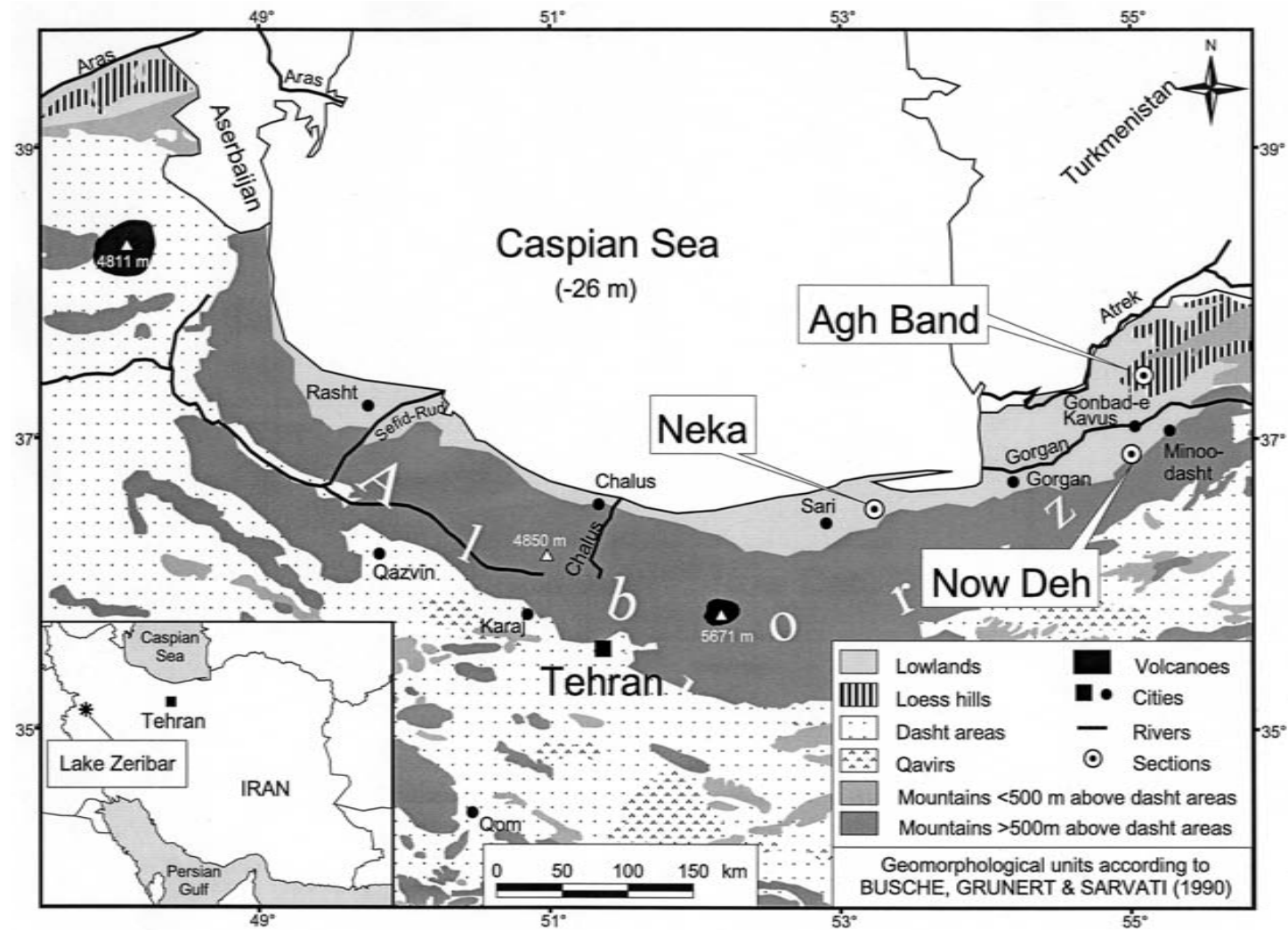

Fig. 1: Geomorphological map of Northern Iran showing the occurrence of loess hills and the location of sections described in the text. "Dasht" is a regional name for bajadas and alluvial plains whereas "qavirs" are claypans (playas) with a naturally high salt content in the endhoreic basins of the highlands.

Abb. 1: Geomorphologische Karte Nordirans mit der Verbreitung von Lösshügelländern (loess hills) und der Lage der im Text beschriebenen Lössprofile. „Dasht“ ist eine regionale Bezeichnung für Fußflächen und fluviale Aufschüttungsebenen (Bajadas und alluvial plains), während „Qavir" für die salzreichen Tonpfannen (Playas) der endhoreischen Becken des Hochlandes steht. 
Tab. 1: Coordinates, altitude and climatic data of the sections under investigation.

Tab. 1: Koordinaten, Höhenlage und klimatische Kenngrößen der beschriebenen Lössprofile.

\begin{tabular}{lccccc}
\hline Location & Latitude & Longitude & Altitude & $\begin{array}{c}\text { Mean annual } \\
\text { precipitation* } \\
{[\mathrm{mm} / \mathrm{a}]}\end{array}$ & $\begin{array}{c}\text { Mean annual } \\
\text { temperature* } \\
{\left[{ }^{\circ} \mathrm{C}\right]}\end{array}$ \\
\hline Neka & $36^{\circ} 39^{\prime} 53^{\prime \prime} \mathrm{N}$ & $53^{\circ} 23^{\prime} 46^{\prime \prime} \mathrm{E}$ & 116 & $\sim 750$ & $\sim 17.0$ \\
Now Deh & $37^{\circ} 05^{\prime} 50^{\prime \prime} \mathrm{N}$ & $54^{\circ} 12^{\prime} 58^{\prime \prime} \mathrm{E}$ & 172 & $\sim 600$ & $\sim 17.5$ \\
Agh Band & $37^{\circ} 37^{\prime} 18^{\prime \prime} \mathrm{N}$ & $55^{\circ} 09^{\prime} 39^{\prime \prime} \mathrm{E}$ & 150 & $\sim 350$ & $\sim 17.0$ \\
\hline
\end{tabular}

* Estimates based on precipitation and temperature data for meteorological stations at the cities of Babolsar, Gorgan and Gonbad-e Kavus

about Quaternary climate change and its effect on landscape evolution in the southern Caspian lowland and its vicinity. Attempts to reconstruct climate history based on fluvial and marine terraces (e.g., EHLERs 1971) are afflicted with large uncertainties because of high rates of tectonic uplift in the Alborz mountains and of subsidence of the Caspian basin. According to pollen spectra, isotope composition and other climate proxies derived from sediments of Lake Zeribar (see inlet of Fig. 1), the LGM in the Western Zagros Mountains was dominated by a dry and cool climate (VAN Zeist \& BotTema 1991; SteVEns, Wright \& ITO 2001) and followed by slowly increasing temperature and rainfall until 6000 a $(6 \mathrm{ka})$ before present (B.P.), when the comparatively warm and moist conditions of modern climate was attained. It might thus be hypothesised that similar climate changes also ocurred in other parts of Iran. However, reliable climate reconstruction based on the analysis of terrestrial or marine climate archives other than the Lake Zeribar cores are still lacking.

\subsection{Sedimentological and paleopedological analysis}

The loess-paleosol sequences were character- ised in the field according to the instructions of AG BoDen (1994). Grain size spectra were determined by wet sieving and the pipette method after destruction of soil organic matter with $\mathrm{H}_{2} \mathrm{O}_{2}$ and dispersion with $\left(\mathrm{NaPO}_{3}\right)_{6}$ and $\mathrm{Na}_{2} \mathrm{CO}_{3}$. Gypsum was leached by repeated washing with deionised water prior to grain size analysis.

Inorganic carbon was measured with the gas volumetric method (Schlichting, Blume \& STAHr 1995) and expressed as $\mathrm{CaCO}_{3}$ equivalent. Organic carbon (OC) was calculated by substracting the total amounts of carbon before and after dry combustion of organic $\mathrm{C}$ (OC) for $5 \mathrm{~h}$ at $550{ }^{\circ} \mathrm{C}$ (Schlichting, Blume \& Stahr 1995). In both cases total carbon was measured with a C/N/S analyzer (Forno EA of Fisons Instruments, Italy). Total carbon after dry combustion yielded slightly higher $\mathrm{CaCO}_{3}$ equivalents than by using the gasvolumetric method. Gypsum was extracted with water and selectively precipitated with acetone as described by VAN ReEuwijK (1995).

For micromorphological investigations, thin sections were prepared for samples marked in Tab. 2, 4 and 5. The denomination of soil horizons widely follows the instructions of FAO (1998). However, loess layers with pedogenic accumulation of calcium carbonate and sharp upper boundary towards the B horizons were 


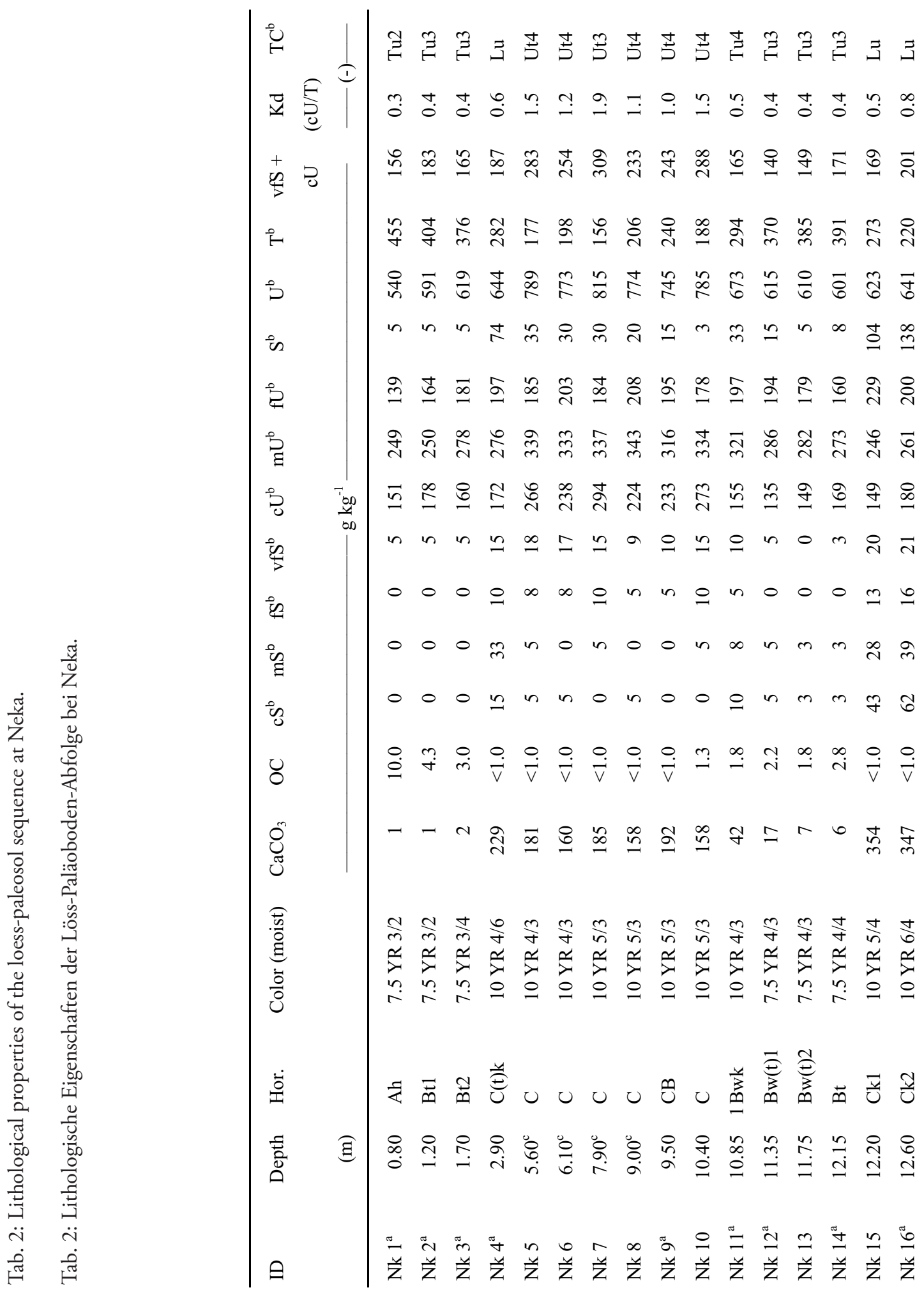




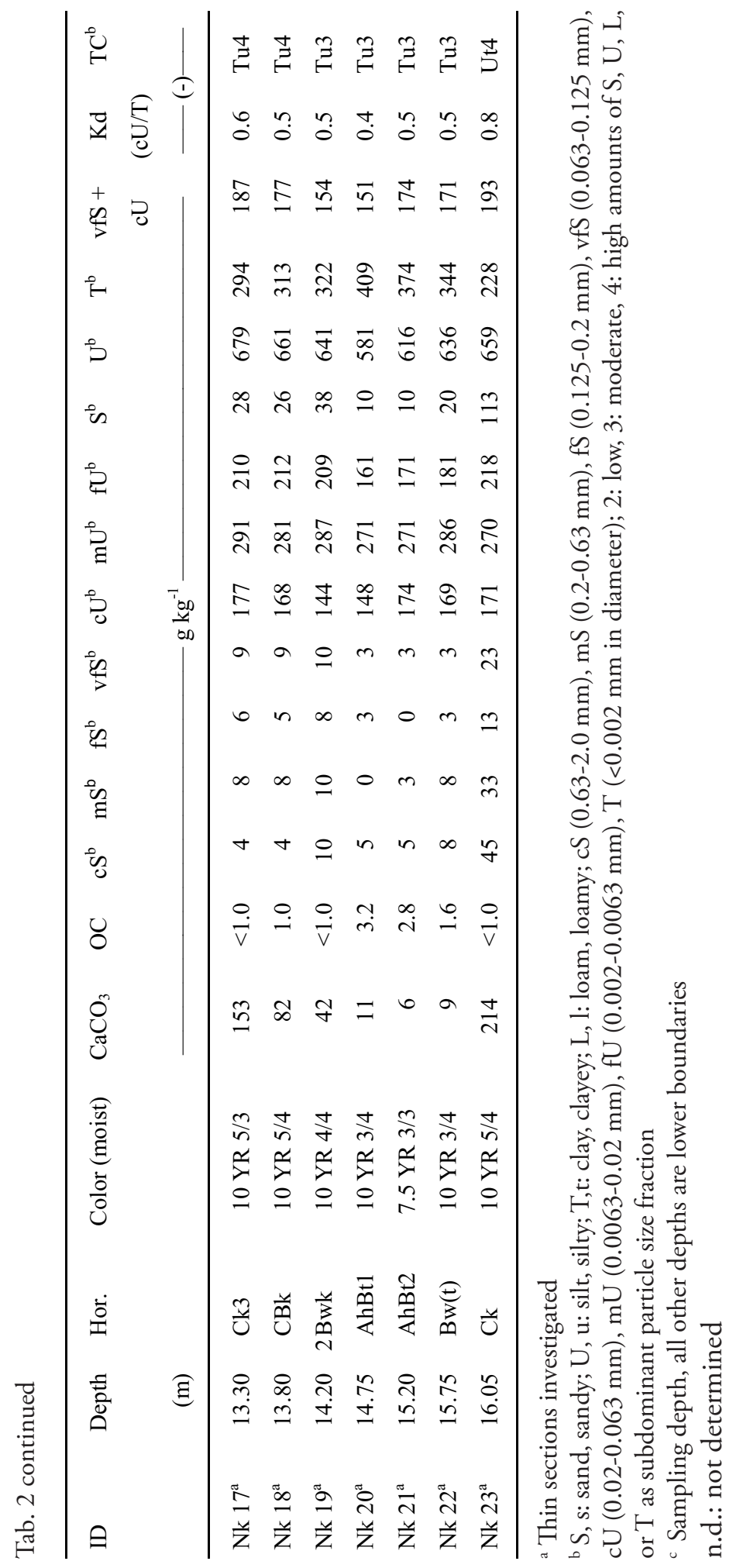


classified as $\mathrm{Ck}$ horizons and not as Bk horizons. CB horizons show clear signs of browning and formation of secondary structure but still contain abundant grains of primary calcite. They are transitional horizons between loess $(\mathrm{C}$ horizon) and Bw horizons. The latter are free of primary calcite grains and have well developed structure. BC horizons as defined by BRONGER, Winter \& Heinkele (1998) were not identified. $\mathrm{Bw}(\mathrm{t})$ horizons have weak clay illuviation, which is not sufficient to classify as Bt horizons, because less than $1 \%$ of pores contain illuviation argillans. Soil color names and notations were determined based on the revised edition of Munsell soil color charts (OYAMA \& TAKEHARA 1992).

\subsection{Experimental details for luminescence dating}

Aeolian sediments like loess and dune sands are particularly suitable for the application of luminescence dating techniques to determine the "deposition age" of the sediments (FRECHEN \& Dodonov 1998; Lang et al. 2003; Wintle \& PaCKMan 1988; Zöller et al. 1994). Luminescence is the light emitted from crystals such as quartz, feldspar or zircon when they are stimulated with heat or light after receiving a natural or artificial radiation dose. The equivalent dose is a measure of the past radiation energy absorbed and, in combination with the dose rate, yields the time elapsed since the last exposure to sunlight. An important assumption of luminescence dating techniques is that the mineral grains were exposed to sunlight sufficiently long enough prior to deposition.

Eight loess samples were taken in light-tight tubes about $250 \mathrm{~g}$ each in the field. Furthermore, about $1 \mathrm{~kg}$ of sediment was sampled for gammaspectrometry to determine the amount of radioactivity in the sediment. Polymineral fine-grained material $(4-11 \mu \mathrm{m})$ was prepared for the measurements, as described by FreCHEN, Schweitzer \& Zander (1996). The material brought on discs were irradiated by a ${ }^{90} \mathrm{Sr}$ beta source in at least seven dose steps with five discs each and a radiation dose up to 750 Gray (Gy). All discs were stored at room temperature for at least four weeks after irradiation. The irradiated samples were preheated for 1 minute at $230^{\circ} \mathrm{C}$. Equivalent dose values were determined using infrared optically stimulated luminescence (IRSL) and the Multiple Aliquot Additive Dose Protocol (MAAD). A Schott BG39/Corning 759 filter combination was placed between photomultiplier and aliquots for the measurements. Each aliquot was hold at a temperature of $50^{\circ} \mathrm{C}$ during 10 seconds of IR decay. Equivalent doses were obtained by integrating the $1-10$ s region of the IRSL decay curves. An exponential growth curve was fitted to the data and compared with the natural luminescence signal to estimate the equivalent dose. The reproducibility of the measurements were excellent so that normalisation was not applied. Alpha efficiency was estimated to $0.08 \pm 0.02$ for all samples. Dose rates for all samples were calculated from potassium, uranium and thorium contents, as measured by gamma spectrometry in the laboratory, assuming radioactive equilibrium for the decay chains. Cosmic dose rate was corrected for the altitude and sediment thickness, as described by Aitken (1985) and Prescott \& Hutton (1994). The natural water content of the sediment was estimated to $15 \pm 5 \%$.

\section{Loess-paleosol sequences}

\subsection{Section at Neka}

East of the city of Sari, loess with a maximum thickness of approximately $20 \mathrm{~m}$ covers Jurassic limestone of the Alborz front hills. At the section at Neka (Tab. 2, Fig. 2), the uppermost 


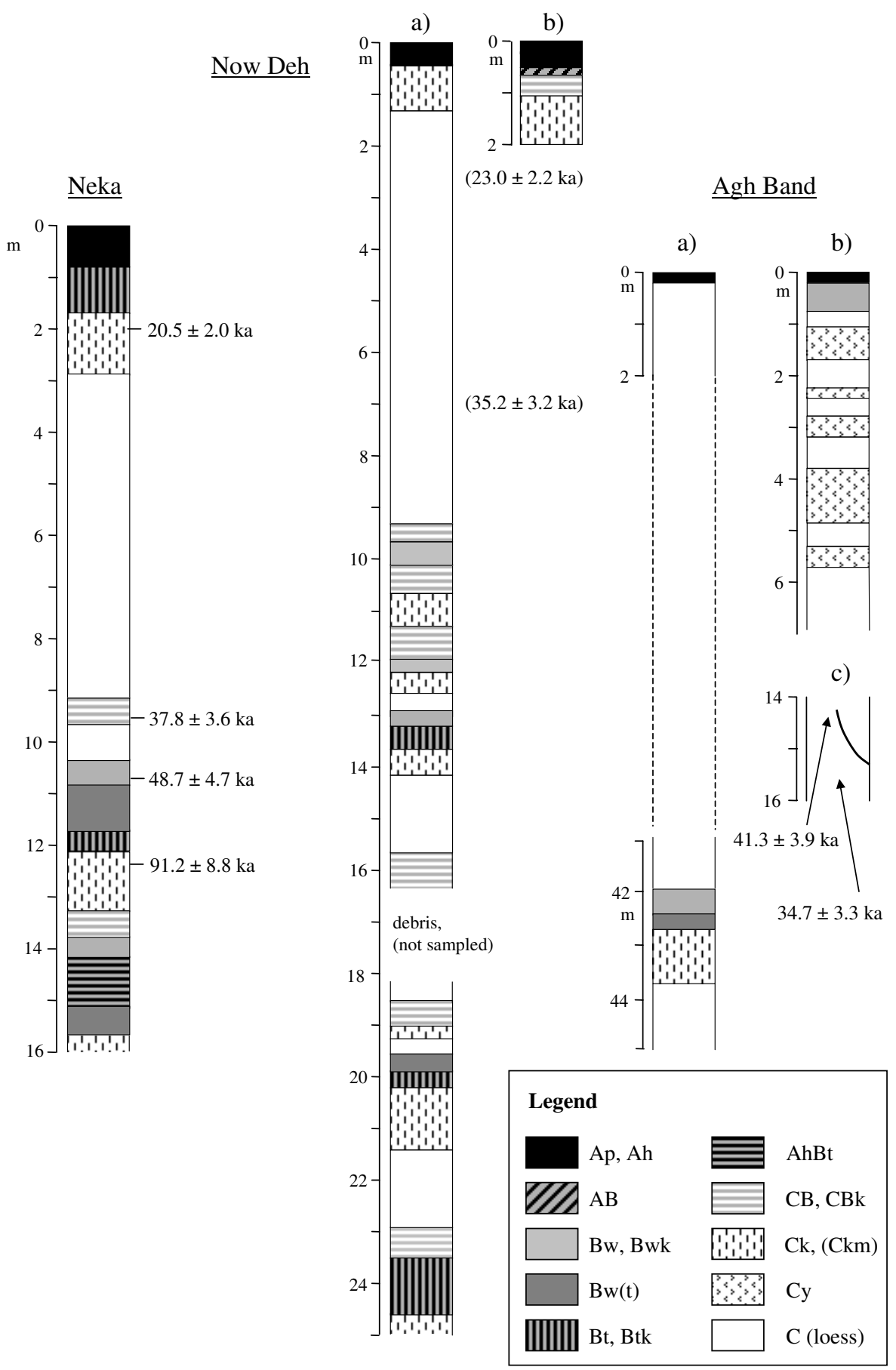

Fig. 2: Loess-paleosol sequences at the sections at Neka, at Now Deh and at Agh Band. Please refer to text for further description.

Abb. 2: Löss-Paläobodenabfolgen bei Neka, Now Deh und Agh Band. Weitere Erläuterungen im Text. 
loess deposit is about $10 \mathrm{~m}$ thick and more or less homogenous with a dull yellowish brown (10 YR 5/4, 10 YR 4/4) color and a $\mathrm{CaCO}_{3}$ equivalent ranging from 158 to $185 \mathrm{~g} \mathrm{~kg}^{-1}$. The grain size modus is in the medium silt fraction and clay contents range from 156 to $240 \mathrm{~g} \mathrm{~kg}$ 1. Weak signs of soil formation including iron oxide mottling and light browning were found in a layer denominated as CB horizon at 9.5 $\mathrm{m}$ depth. Underneath this horizon a strongly developed brown (7.5 YR 4/3) paleosol with $\mathrm{Bw}(\mathrm{t})$, Bt horizons at a depth of about $12 \mathrm{~m}$ and a very strong, brownish black (7.5 YR 3/2) paleosol (AhBt, Bw(t) horizons) at $15 \mathrm{~m}$ depth including horizons of carbonate enrichment (Ck) are exposed. Both paleosols have well-developed nut-shaped to angular blocky structure. Clay skins are apparent in the lower horizon of the first paleosol and in the strongly developed AhBtk horizons of the lower paleosol. White patches of secondary calcite and some carbonate concretions show some re-calcification from the overlying loess. However, the $\mathrm{CaCO}_{3}$ equivalents of the paleosol horizons do not exceed $17 \mathrm{~g} \mathrm{~kg}^{-1}$ (Tab. 2). On top of both paleosols, weakly developed light brown (10 YR 4/4) and carbonate enriched Bwk horizons occur. These horizons are genetically not related to the $\mathrm{Bw}(\mathrm{t})$ or AhBt horizons of the two strongly developed paleosols. The Bwk horizons thus indicate a polycyclic soil genesis including soil formation, truncation of the upper soil horizons, loess deposition and again soil formation. Therefore, the paleosols represent at least two and possibly four periods of soil formation interrupted by loess deposition.

According to luminescence measurements, samples NK3 and NK4 taken from above and below the first paleosol gave IRSL age estimates of $48.7 \pm 4.7 \mathrm{ka}$ and $91.2 \pm 8.8 \mathrm{ka}$ (Tab. 3), respectively. It is likely that this paleosol correlates with OIS $5 \mathrm{a}$ or $5 \mathrm{c}$. The lower paleosol with AhBtk horizons might therefore correlate at least with the last interglacial but more lumi- nescence age estimates are required to solve the chronostratigraphical problem.

The loess deposit above the two paleosols correlates probably with OIS 3 to OIS 2. An IRSL age estimate of $37.8 \pm 3.6 \mathrm{ka}$ (sample NK2 of Tab. 2) was determined for the CB horizon at $9.5 \mathrm{~m}$ depth. A sample taken $20 \mathrm{~cm}$ from below the modern Bt horizon gave an IRSL age estimate of $20.5 \pm 2.0 \mathrm{ka}$ indicating that the uppermost loess was deposited during the late glacial maximum (LGM).

The modern soil can be classified as Typic Argixeroll (Soll Survey Staff 1999) or Luvic Phaeozem (FAO 1998) characterised by a thick Ah horizon covering a strongly developed $\mathrm{Bt}$ and a Ck horizon. The modern soil resembles the AhBtk horizon between 14.10 and $15.80 \mathrm{~m}$ below surface rather than the $\mathrm{Bw}(\mathrm{t})$ and $\mathrm{Bt}$ of the upper strong paleosol.

\subsection{Section at Now Deh}

About $20 \mathrm{~km}$ southeast of Gonbad-e Kavus, the Now Deh river (Rieben 1966) dissects a more than $25 \mathrm{~m}$ thick sequence of dull yellowish brown (10 YR 5/4) loess covering weathered limestone that dips to the northwest. Nine paleosols are intercalated in the loess exposed in two steep vertical undercut slopes, which parallel the anticlinal shape of the bedrock. Since there is no dislocation of the paleosols or other indication of modern tectonic activity, the term 'recent folded loess' of Rieben (1966) is confusing. It is more likely that the anticlinal shape of the loess-paleosol sequence results from mantling a pre-existing land surface.

At the northernmost cut of the river the loess is divided by four weakly to moderately developed and three strongly developed paleosols represented by $\mathrm{CBk}$, Bwk and $\mathrm{Bt}$ horizons (profile a in Fig. 2). At the top of the sequence, a Ck horizon is exposed, similar to $\mathrm{Ck}$ horizons 


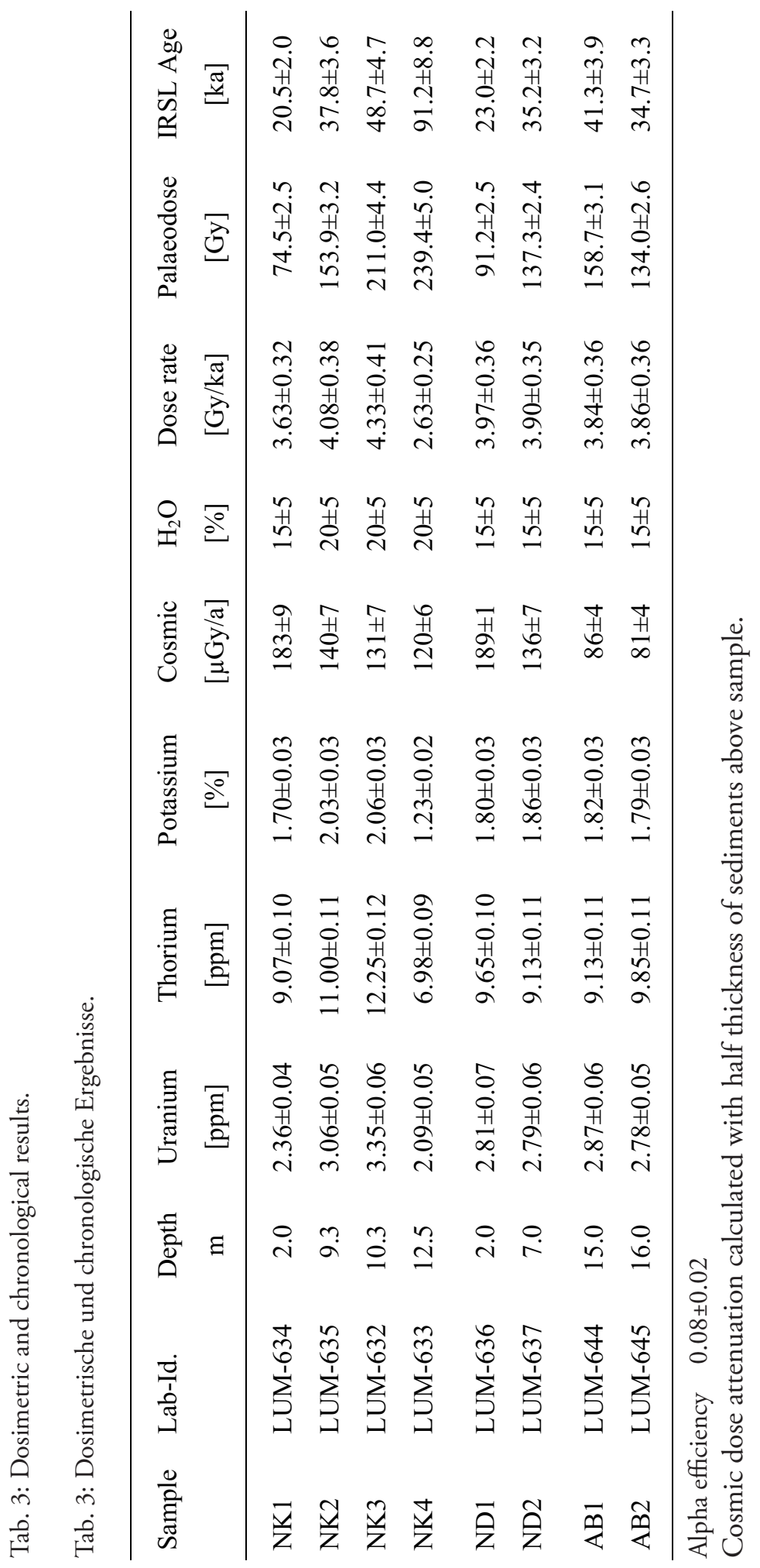


of modern soil in the area under study. The modern soil has been sampled at profile $b$ of Fig. 2, located about $200 \mathrm{~m}$ south of profile a and on the backward site of the river cut shown in Fig. 3. The modern soil at profile $b$ is under rainfed agriculture and appears to be truncated by soil erosion. However, Bt horizons were not found and the soil classifies as Typic Calcixeroll (Soil Survey Staff 1999) or Calcic Chernozem (FAO 1998). According to field observation in a nearby location with an altitude of about 350 $\mathrm{m}$ and possibly higher mean annual rainfall, the modern soil has a Bt horizon covered by a thick Ah horizon. This soil resembles the modern soil at the section at Neka. However, clay cutans are less clear and appear to be less well-developed likely owing to lower annual precipitation in Now Deh.

Below the $\mathrm{Ck}$ horizon of profile a about $8 \mathrm{~m}$ of homogenous loess are exposed, which has the same color as the uppermost loess of Neka. The grain size distribution shows slightly higher clay percentages and higher portions of very fine sand and coarse silt (vfS $+\mathrm{cSi}$ in Tab. 2, 4) in Now Deh. Accordingly, the coefficient of coarse silt/clay is slightly lower. At Now Deh some loess layers contain pseudomycelia of secondary calcite possibly indicating a weak synsedimentary soil formation. The $\mathrm{Ck}$ horizons found immediately below $\mathrm{CBk}$, Bwk or Bt horizons described below have abundant carbonate concretions and nodules and/or patches of secondary calcite. Locally, calcite enrichment causes a moderate cementation like in the $\mathrm{Ck}$ horizon directly beneath the lowermost Bt horizon.

In profile a, five weakly to moderately developed dark brown to brown paleosols (10 YR 3/ 3 to 10 YR 4/4) are exposed at about 9.5, 11.5, 13.0, 16.0 and $18.75 \mathrm{~m}$ below surface. The CBk and Bwk horizons of these paleosols have massive to weak subangular blocky or weak angular blocky structure and black manganese or humus mottles. Pseudomycelia and patchy carbonate accumulations show secondary ac- cumulation of carbonate. Leaching intensity and/or time of soil formation were apparently not sufficient to decalcify the paleosols completely as a precondition for clay illuviation. Accordingly, comparatively thin $\mathrm{Ck}$ horizons are found below the $\mathrm{CBk}$ and Bwk horizons, whereas the $\mathrm{Ck}$ horizons underneath the Bt horizons exposed at 13.5, 20 and $24 \mathrm{~m}$ below surface are considerably thicker owing to a much higher amount of carbonate enrichment. The (reddish) dark brown Bt horizons (7.5 YR 3/4) display a strong fine to coarse angular blocky to prismatic structure and clear clay coatings. They have higher clay contents (Tab. 4) and according to field evidence also higher bulk densities than the CBk or Bwk horizons. The two upper Bt horizons are thin compared to the lower one. As their thickness does not correspond to the ones of the related $\mathrm{Ck}$ horizons the truncation of the upper part of the Bt horizons by erosion is very likely.

Below the Bt horizon at $24 \mathrm{~m}$ depth a further strongly developed paleosol (possibly a Bt horizon) was not accessible for description and sampling (not shown in Fig. 2, Tab. 4). This paleosol is found at a depth of about $27 \mathrm{~m}$ below surface and forms a thick pedocomplex with the CBk horizon at $18.75 \mathrm{~m}$ and the two Bt horizons at $20 \mathrm{~m}$ and $24 \mathrm{~m}$ depth about $20 \mathrm{~m}$ downstream of the profile a. This pedocomplex is also visible in the left half of Fig. 3 showing a river cut about $200 \mathrm{~m}$ upstream of the described section. In this cut, a strongly developed $\mathrm{Bt}$ horizon ( $9^{\text {th }}$ paleosol, not sampled) is exposed at $2.5 \mathrm{~m}$ depth below the latter pedocomplex (Fig. 3).

Two IRSL samples were taken in a profile about $30 \mathrm{~m}$ north of profile a from 2 and $7 \mathrm{~m}$ below surface and above the first Bwk horizon to set up a first chronological frame. The samples ND1 and ND2 gave IRSL age estimates of 23.0 $\pm 2.2 \mathrm{ka}$ and $35.2 \pm 3.2 \mathrm{ka}$, respectively (Tab. 2). These results are in agreement with IRSL age estimates of loess from the section at Neka. However, in the river cut $200 \mathrm{~m}$ upstream of 


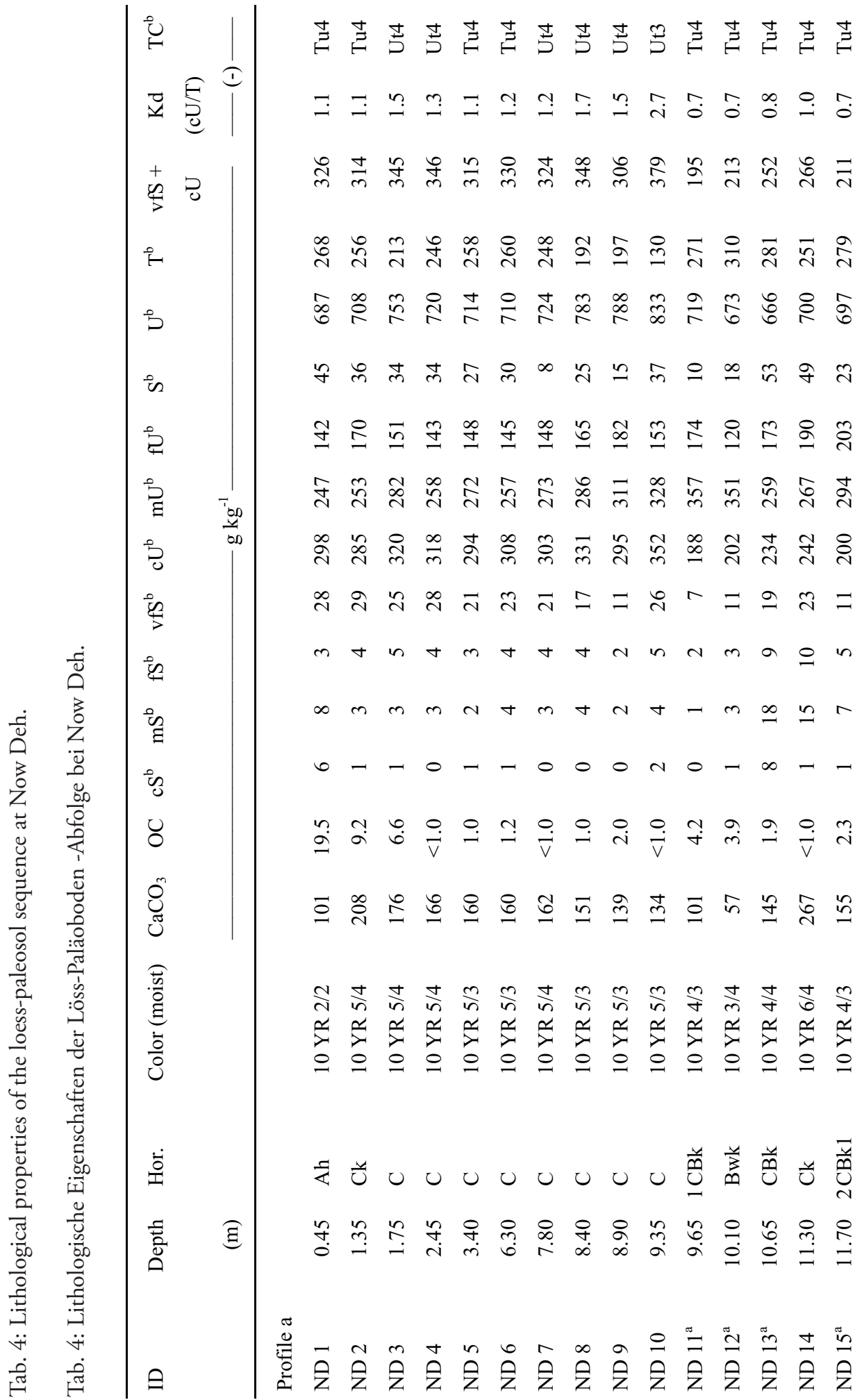




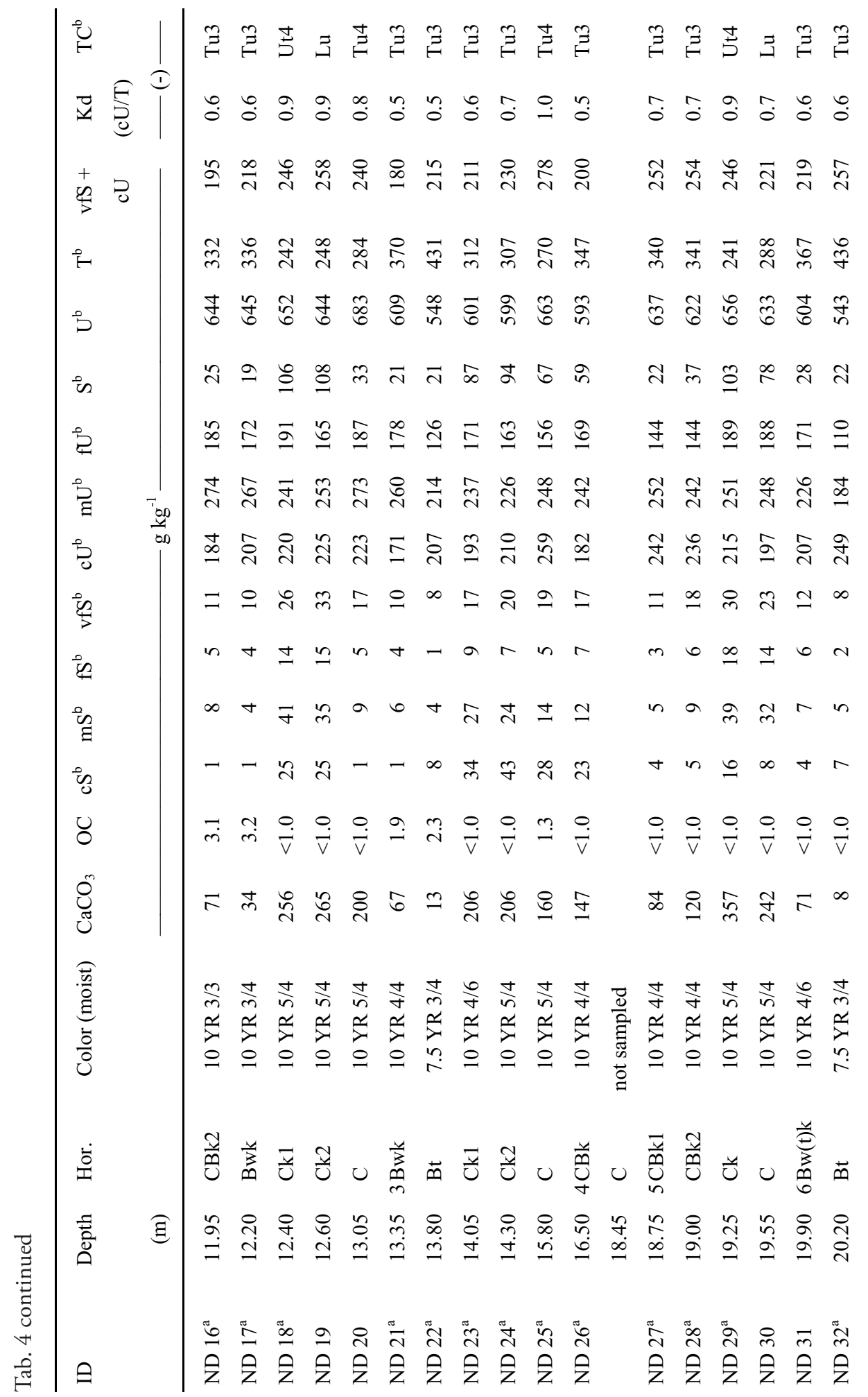




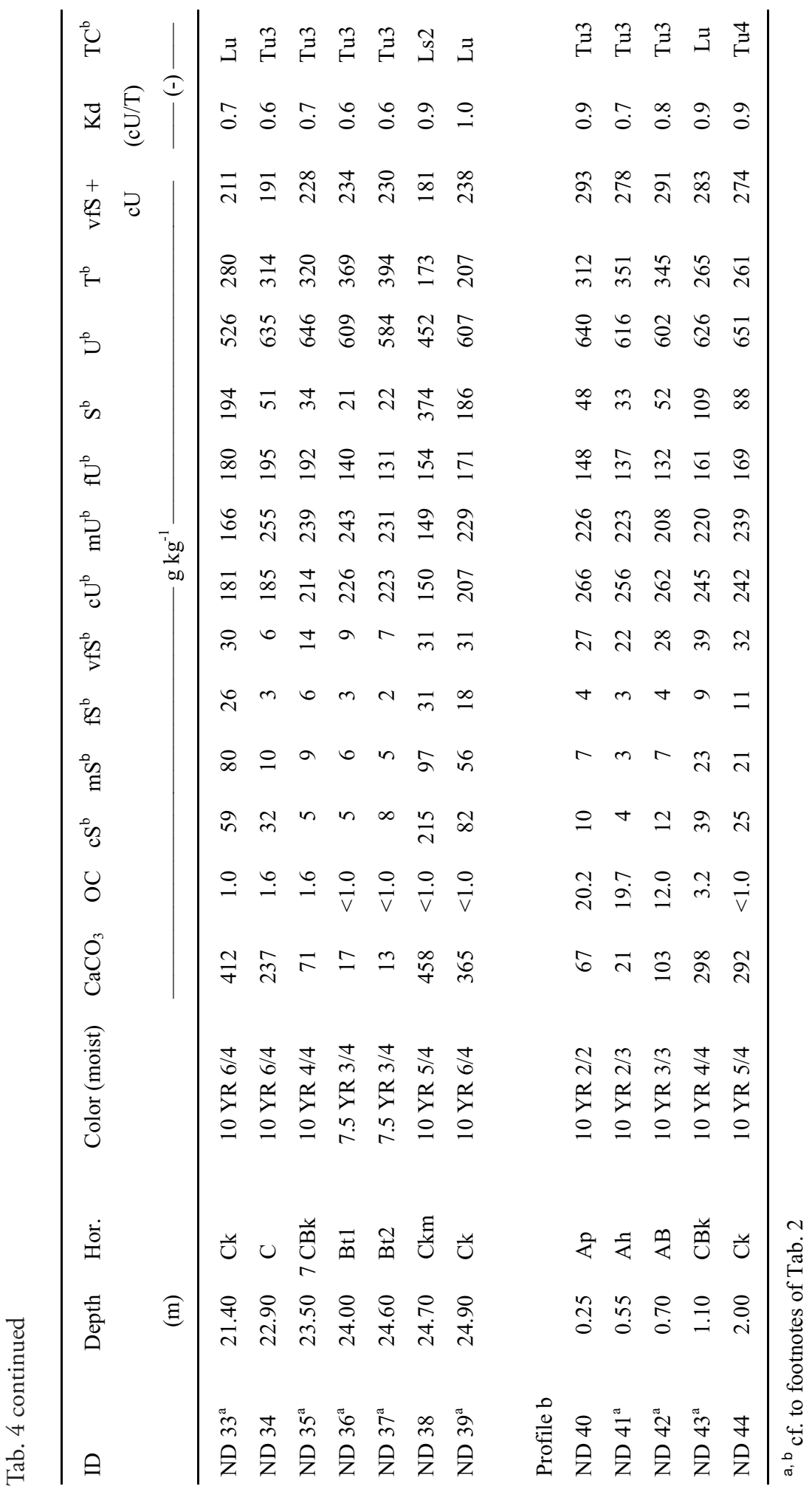




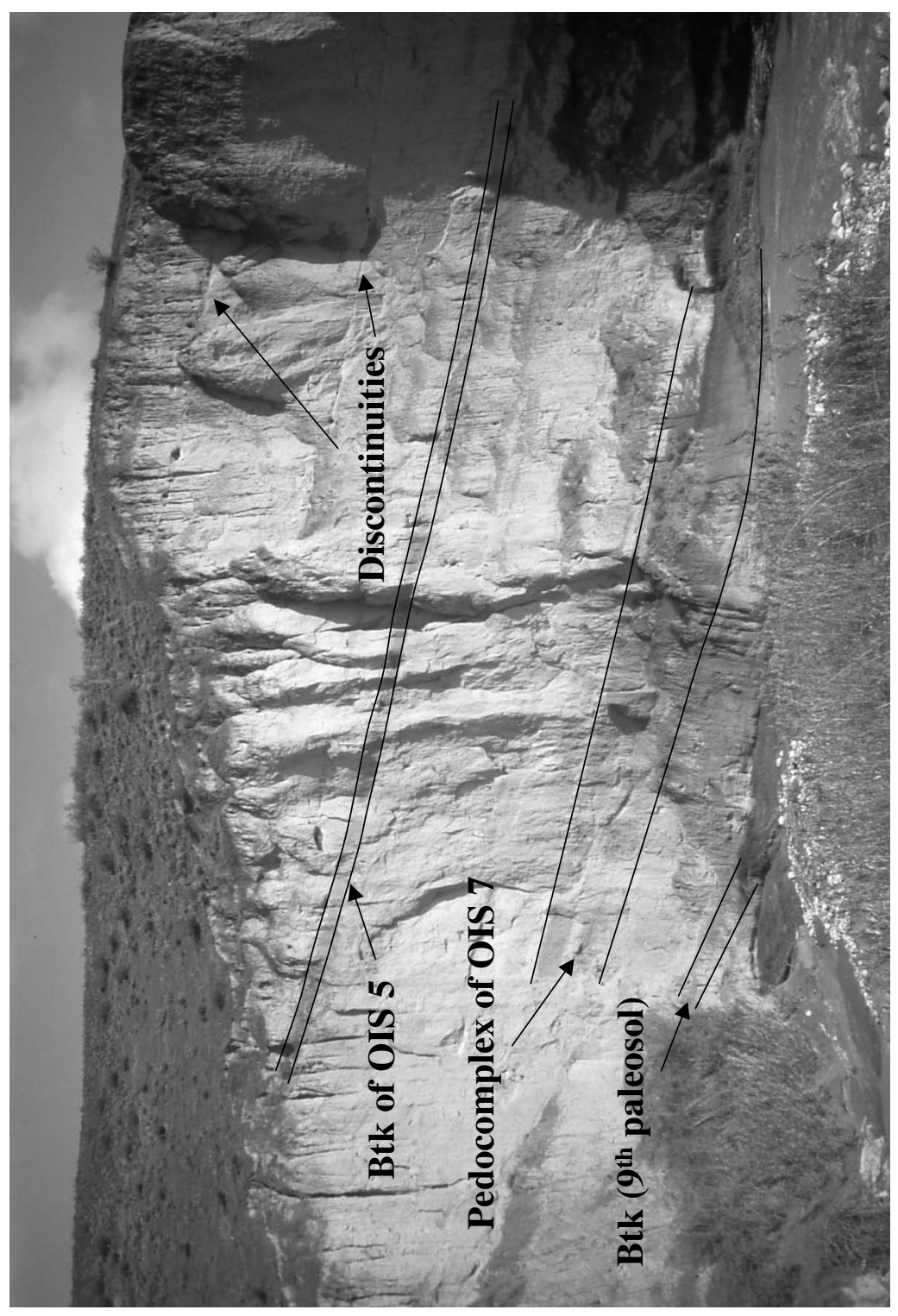

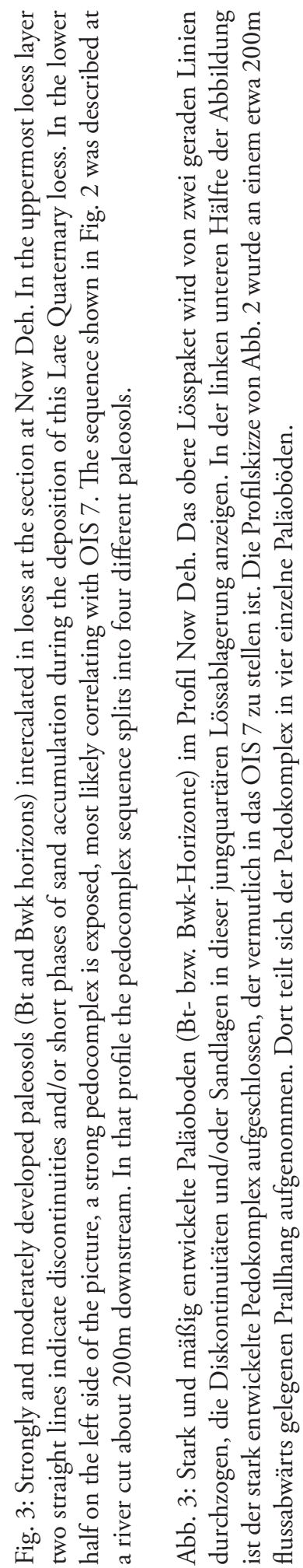


the section at Now Deh, two discontinuities are intercalated in the loess above the first paleosol horizon (Fig. 3). These discontinuities were not observed in profile a (Fig. 2).

According to these first age estimates and based on loess-paleosol stratigraphy in Europe, it is very likely that the first Btk horizon at $13.5 \mathrm{~m}$ depth correlates with the last interglacial (OIS 5e), whereas the moderately developed brown Bwk horizons from above the Btk represent interstadials of OIS 3 to $5 \mathrm{~d}$ and the one from below this Btk of OIS 6. The paleosols of the pedocomplex, at 18.75, 20 and $24.5 \mathrm{~m}$ below surface, are tentatively correlated with the penultimate and antepenultimate (OIS 7 and OIS 9) or older interglacial periods.

\subsection{Section at Agh Band}

In the vicinity of the section at Agh Band steeply sloping loess hills rise about 50 to $70 \mathrm{~m}$ above the valley floors forming the picturesque landscape of the so-called Iranian loess plateau. These hills are covered by grassland with small shrubs mainly situated on the northward facing slopes. Overgrazing in connection with intense rainfall causes serious erosion by episodic surface runoff and piping. The strong dissection of the plateau by deep valleys raises the question, whether the drainage system of the plateau was formed during a period of higher precipitation, e.g., in early Holocene time. Finely laminated lake deposits more than $8 \mathrm{~m}$ thick cover some of the valley floors between the loess hills. The lake sediments have been subsequently eroded and incised at least during Holocene times. These sediments give evidence for the existence of a lake for many hundreds or thousands of years after loess deposition had ceased. The lake sediments correlate most likely with a pluvial period including a significant higher groundwater table than today.
The section at Agh Band was investigated in three different profiles (profile a, b and $\mathrm{c}$ in Fig. 2). The loess hills are composed of more or less homogenous dull yellowish brown (10 YR $5 / 3)$ to yellowish brown (2.5 Y 5/3) loess rich in chlorite, mica and gypsum. The loess has a grain size maximum in the coarse silt fraction, high amounts of very fine sands and maximum Kd values $>10$. It is considerably coarser than the loess at Neka or Now Deh. Profile a of the section at Agh Band was described along a steeply inclined southward facing slope (inclination about $50^{\circ}$ ) of one of the loess hills. About $40 \mathrm{~m}$ thick loess deposits cover a brown paleosol with well-developed Bwy (10 YR 4/4) and $\mathrm{Bw}(\mathrm{t})(10 \mathrm{YR}$ 5/4) horizons superimposing an older loess that resembles the upper loess deposit. The paleosol has moderate subangular blocky structure, patches of secondary gypsum and few calcite pseudomycelia and concretions. Based on the resemblance to subsoil horizons of Typic Calcixerepts that were mapped as modern soils of the area (SWRI 2000), the paleosol possibly correlates with the last or penultimate interglacial soil, most likely OIS 5e. However, independent age control is not available and we did not find an undisturbed modern soil for comparison yet.

About $300 \mathrm{~m}$ to the east of the first profile (a), a road cut exposes the loess of profile $b$. Here the loess is intercalated by several horizons with secondary gypsum (Cy horizons) or characterised by weak iron oxide mottling indicating initial to weak soil formation during deposition of the apparently homogenous thick loess deposit. At the top of profile $\mathrm{b}$ a weakly developed modern soil with Ah (10 YR 4/2) and weak Bw (2.5 Y 4/3) horizons superimposes the loess. It is most probable that this soil formed after erosion of the modern climatic climax soil. Profile b is located stratigraphically above the tentatively last interglacial paleosol of profile a and about $100 \mathrm{~m}$ north of profile $\mathrm{c}$, which was sampled for IRSL dating (Fig. 5). The samples AB1 and AB2 


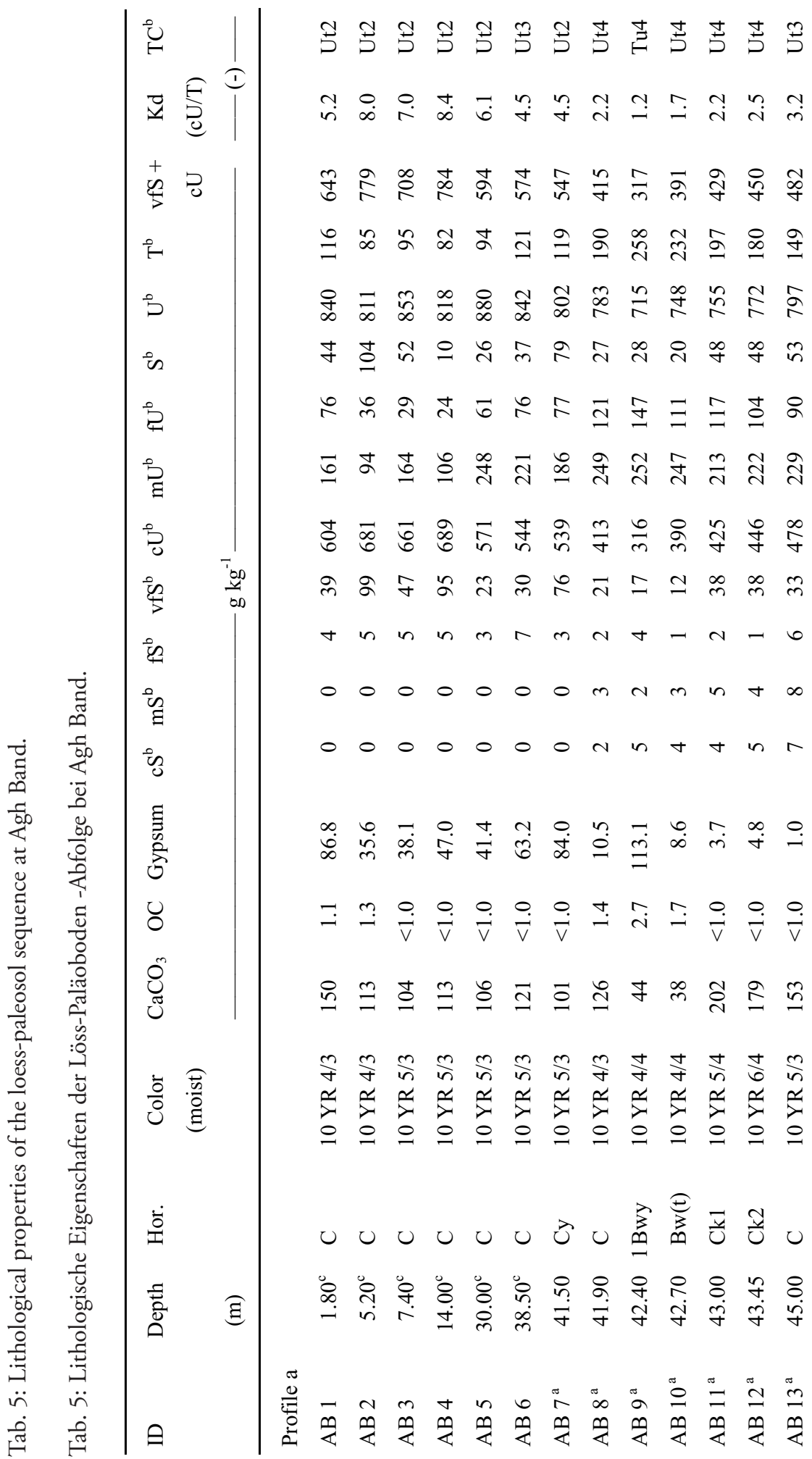




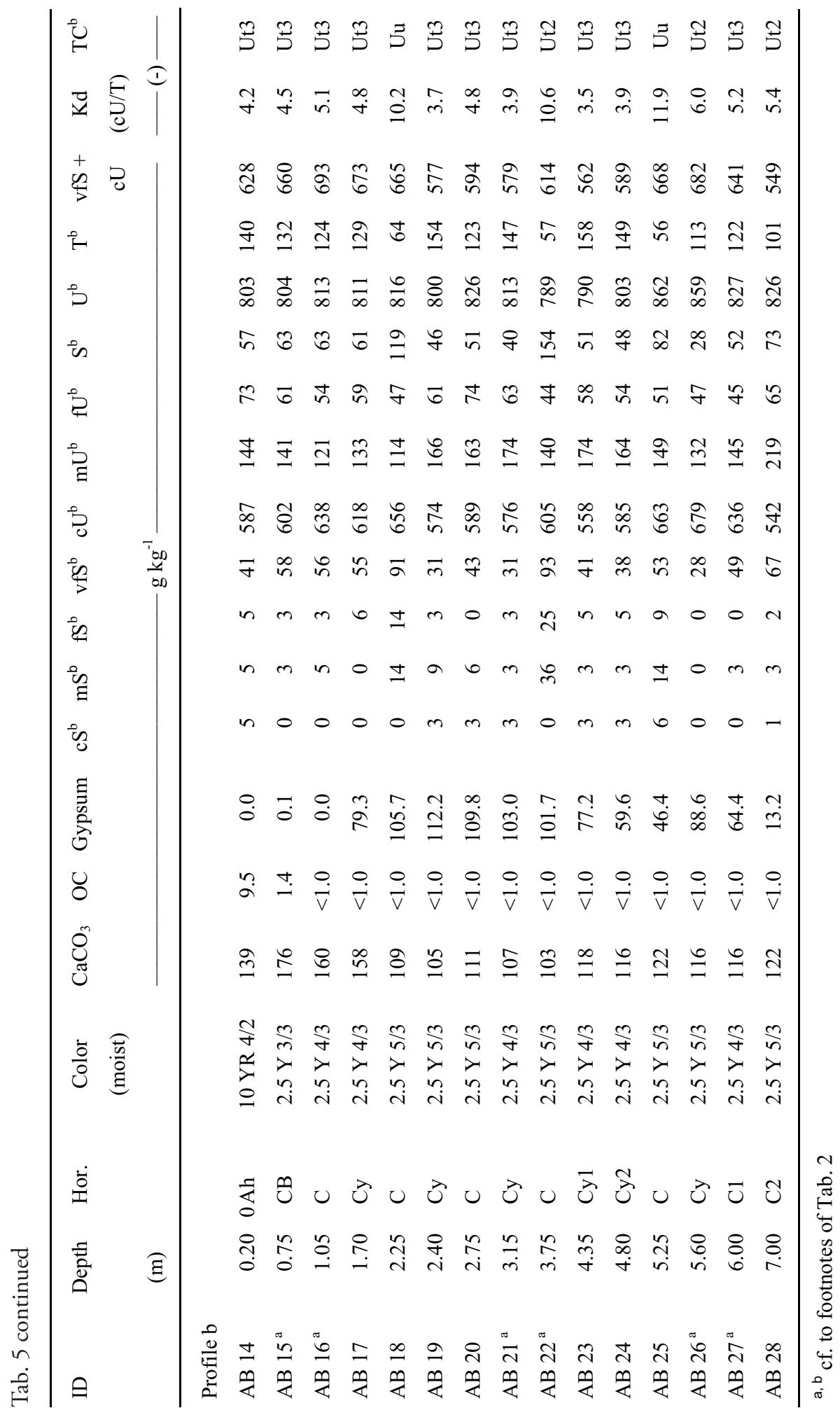


were taken with a vertical distance of $1 \mathrm{~m}$ and yielded age estimates of $41.3 \pm 3.9 \mathrm{ka}$ and 34.7 $\pm 3.3 \mathrm{ka}$, respectively (Tab. 2) indicating that deposition of this loess layer took place during OIS 3 of the last glacial. The two IRSL age estimates are in agreement within the 1-sigma standard deviation. Both samples were taken from below a fault line dipping to the northeast, most likely owing to a small land slide following heavy rain-fall or a much higher water table during a pluvial time or earthquakes. Recent small and shallow land slides are often found on the steeply inclined slopes of the loess hills.

\section{Discussion}

The three loess-paleosol sequences show differences in thickness, grain size distribution and numbers and types of paleosols (Fig. 2, 4). The uppermost unweathered loess deposits in Neka, Now Deh and Agh Band are about $10 \mathrm{~m}, 13$ $\mathrm{m}$ and $40 \mathrm{~m}$ thick, respectively, suggesting different mass accumulation rates during the last glacial. Mean grain size decreases in a $\mathrm{N}$ $S$ direction from Agh Band to Now Deh (and Neka) as already observed by LATEeF (1988). The granulometric composition of Agh Band loess resembles the one of loess deposits at the northern footlopes of Kopet Dagh in northeastern Iran (OKhravi \& Amini 2001). The much finer loess facies at Neka and Now Deh compares to the fine loess facies accumulated in the piedmonts of Tien-Shan and Pamir-Alay in Tajikistan, e.g., in the uppermost loess deposits of the key section at Darai Kalon (Frechen \& Dodonov 1998). Thickness and mean grain size of loess are functions of dust availability in the source areas, proximity to the dust source area, maximum wind velocities and dust trapping efficiency of the vegetation. The high content of fine sand and coarse silt in Agh Band indicates the close proximity to the dust source area, whereas long-distance transport might have contributed the fine component in Now Deh and Neka. Long-distance transport from valleys, flood plains and deserts of Central Asia was made responsible for loess deposition in Uzbekistan and Tajikistan that occurs up to an altitude of 2,500 $\mathrm{m}$ above sea level (Dodonov 1991). The loess cover on the foot hills near the section at Now Deh does not exceed an altitude of $500 \mathrm{~m}$ (LATEEF 1988).

It is thus likely, that most of the dust in Northern Iran derived from local floodplains of the rivers Atrek and Gorgan. Unlike in Tajikistan, dust transporting winds possibly did not attain high altitudes. Assuming a paleowind direction from north to south, dry areas emerged during Caspian Sea lowstands might have been a dust source, as well. During regressions of the Caspian Sea, the gain in land surfaces along its southern coast was probably low, because the southern lowlands are narrow and have a steep slope towards the interior lake basin. West of the present Turkmen shoreline a large shelf area emerged during the Yenotaevian regression (24$17 \mathrm{ka}$ ), though (Mamedov 1988). However, it is not clear, whether the lake floor was dry to allow dust entrainment or was covered by vegetation as assumed for emerged continental shelves in the coastal oasis model (FAurÉ, Walter \& Grant 2002).

The unweathered loess layers of each section are texturally and in relation to the calcium carbonate content also mineralogically more or less homogenous. Also, the sequences do not show any indication of groundwater influence. The degree of soil development reflected in the different types of paleosol horizons depends on climatic conditions and duration of soil formation during interstadial and interglacial periods, only. These paleosols can be defined as climaphytomorphic, which allows us to use them for paleoclimatic reconstructions. The morphology of modern soils at the different sections reflect the recent climatic gradient. The 


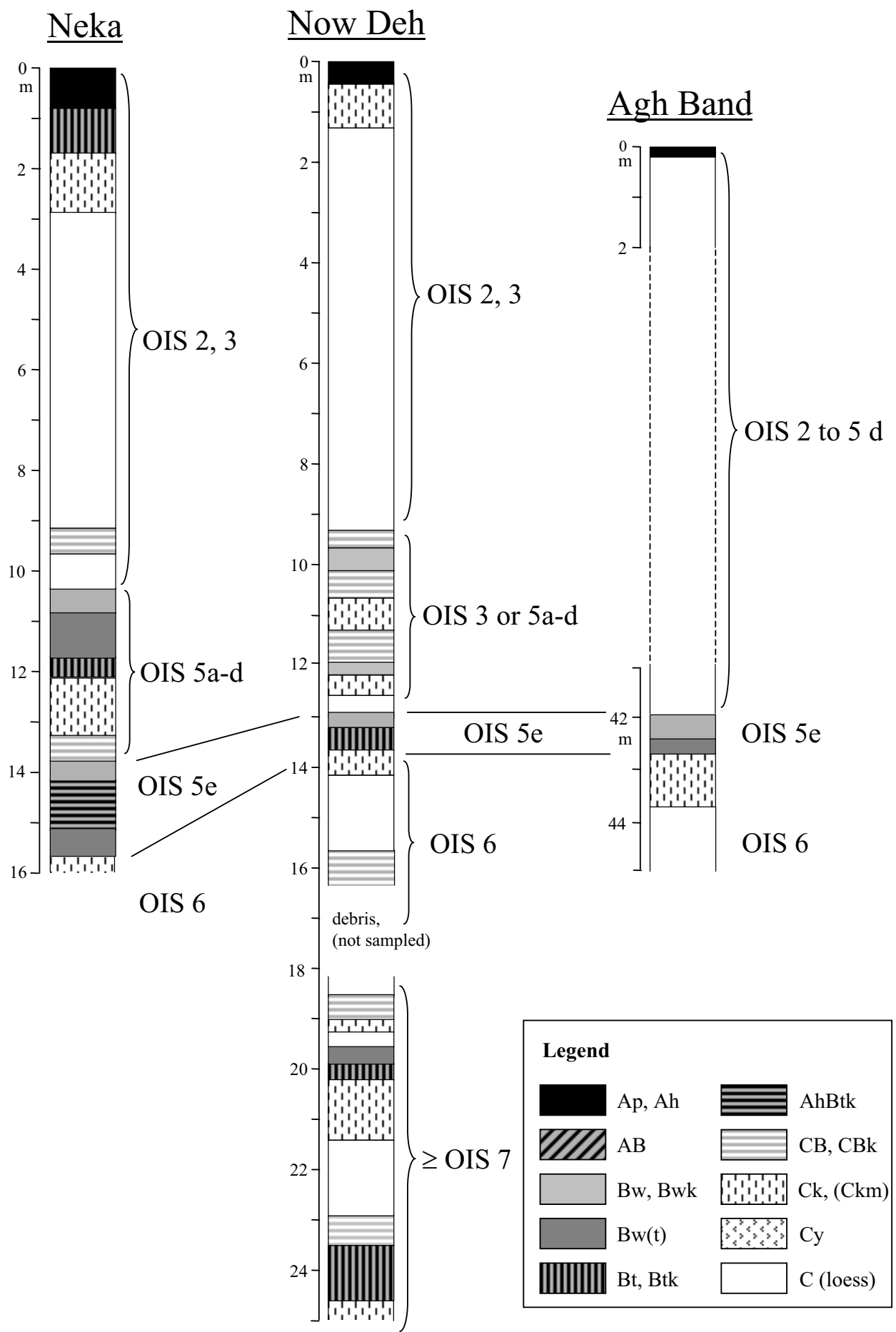

Fig. 4: A pedostratigraphical tramework for loess-paleosol sequences of Northern Iran.

Abb. 4: Pedostratigraphische Einordnung der Löss-Paläobodenabfolgen Nordirans. 
tentatively last interglacial paleosol has strongly developed AhBtk horizons at the section at Neka, moderately to strongly developed Bt horizons at Now Deh and moderately developed $\mathrm{Bw}(\mathrm{t})$ horizon at Agh Band. This indicates similar climatic gradients during the past. However, an undisturbed Holocene soil in the loess hills near Agh Band has not yet been found and further studies to establish mineralogical homogeneity of the parent materials are necessary.

As A horizons were not found, all paleosols were truncated before loess deposition started again. Instead, weakly developed brown paleosols (Bwk) were found on top of strongly developed $\mathrm{Bw}(\mathrm{t})$, Bt or AhBt horizons. This leads to the hypothesis that soil genesis was polycyclic, which is well documented in the pedocomplex of OIS 7 at Now Deh that splits in distinct paleosol horizons and intercalated loess layers at the section described. Paleosols up to $4 \mathrm{~m}$ thick and pedocomplexes of the same thickness were described for loess sections in Uzbekistan and Tajikistan (Lazarenko 1984; Malyanov, Kasymov \& Shermatov 1987; Dodonov 1991; Bronger, Winter \& Heinkele, i 998 , FreChen \& Dodonov i998). It appears that the Central Asian sequences are more detailed than the Chinese loess-paleosol sequences with pedocomplexes in Central Asia representing single paleosol horizons in China (BRONGER, 2003). The loess-paleosol sequences of Northern Iran then rather resemble the Central Asian than the Chinese sequences.

The loess deposits at Neka and Now Deh are much thinner including less pedocomplexes and paleosols than key sections in Uzbekistan or Tajikistan, the latter reaching a thickness up to $200 \mathrm{~m}$ and likely encompassing the whole Pleistocene. However, the Iranian sequences might allow at least an equally good pedostratigraphic resolution of the last glacial/interglacial cycle, because they include several weakly to moderately developed paleosols. Paleosols of the last glacial/interglacial cycle are likely not well preserved in Uzbekistan and Tajikistan. According to Bronger, Winter \& Heinkele (1998) the Karamaydan section in Tajikistan does not contain interstadial paleosol horizons of the last glacial, partly because the uppermost loess is lacking. At the section at Darai Kalon, weak carbonate accumulation horizons but not complete paleosols were correlated with the last glacial (Frechen \& Dodonov 1998). Correlation of the $3^{\text {rd }}$ or even $4^{\text {th }}$ pedocomplex with OIS 5e (Lazarenko 1984, Dodonov 1991) would place the first two or three pedocomplexes into the last glacial. These correlations are likely invalid, as recent absolute age assessments have shown (Zhou, Dodonov \& Shackleton 1996, Frechen \& Dodonov 1998).

A first chronstratigraphic framework of loess deposition and paleosols formation for the sections under study is presented in Fig. 4. Systematic absolute age determinations are needed to verify the chronostratigraphic position of the different paleosols. The strongly developed AhBt horizons in Neka might be good stratigraphic markers because of their dark color.

According to additional field observations near Neka, the loess record in Northern Iran probably reaches far into the Middle Pleistocene. In a quarry not accesible for sampling during this study at least eight strongly developed brown or dark brown paleosols or pedocomplexes divide a $25 \mathrm{~m}$ high loess deposit. In Northern Iran, there might thus be the potential to study considerably longer loess records than described here.

\section{Conclusion}

During the Late and Middle Pleistocene pronounced changes from dry and cold to more or less humid and warm climatic conditions occured in Northern Iran. The section at Now Deh gives evidence for at least nine periods of loess accumulation interrupted by interglacial 
and most probably also interstadial phases of soil formation.

The uppermost loess deposit probably formed during the last glacial. Paleosol horizons likely testify interglacial and interstadial phases of soil formation. In many cases paleosol horizons group to form pedocomplexes, the latter representing polycyclic soil genesis.

The paleosols reflect a trend of increased paleoweathering intensity from the now semiarid loess plateau at Agh Band to the subhumid foothills of Now Deh and Neka. Rates of loess deposition likely experienced an opposite trend.

The loess-paleosol sequences of Northern Iran are excellent archives of climate and environment change for the time period of the Middle and Upper Pleistocene. Systematic absolute age assessments are needed for further correlation of Northern Iranian loess with loess deposits of Central Asia and SE Europe and with the global climatic record.

\section{Acknowledgment}

We thank the University of Tehran and the Shahid-Beheshti University (Tehran) for help in logistic affairs. This is part of an ongoing study funded by the German Research Foundation (Deutsche Forschungsgemeinschaft, DFG-Gz. Ke 818/4-1 and Fr 877/9-1).

\section{References}

AG Boden (1994): Bodenkundliche Kartieranleitung. - 4. Anfl., 392 S., 33 Abb., 91 Tab.; Hannover (E. Schweizerbart).

Aitken, M.J. (1985) : Thermoluminescence Dating. - 359 S., 42 Abb., 62 Tab.; Oxford (Oxford University Press).
Barbier, R. (1960): Découverte de loess et d'une ancienne vallée remblayé dans le cours inférieur du Séfid-Roud (versant nord de l'Elbourz, Iran). - C. R. Acad. Sc. Paris, 250: 1097-1098; Paris.

Bовек, H. (1937): Die Rolle der Eiszeit in Nordwestiran. - Z. Gletscherk., 25: 130-183, 13 Abb., 17 Photos; Berlin-Zehlendorf.

Bronger, A. (2003): Correlation of loess-paleosol sequences in East and Central Asia with SE Central Europe: towards a continental Quaternary pedostratigraphy and paleoclimatic history. - Quat. Int., 106/107: 11-31, 7 Fig.; Oxford.

Bronger, A. \& Heinkele, T. (1989): Paleosol sequences as witnesses of Pleistocene climatic history. - Catena Suppl., 16: 163-186, 6 Fig.; Gießen.

Bronger, A., Winter, R. \& Heinkele, T. (1998): Pleistocene climatic history of East and Central Asia based on paleopedological indicators in loess-paleosol sequences. - Catena, 34: 1-17, 10 Fig.; Amsterdam.

Bronger, A., Winter, R. \& Sedov, S. (1998): Weathering and clay mineral formation in two holocene soils and in buried paleosols in Tajikistan: towards a Quaternary paleoclimatic record in Central Asia. - Catena, 34: 19-34, 11 Fig.; Amsterdam.

Busche, D., Grunert, J. \& Sarvati, R. (1990): Iran Geomorphologie. - Tübinger Atlas des Vorderen Orients (TAVO), A III 3, 1 Map; Tübingen.

Derbyshire, E., Kemp, R.A. \& Meng, X. (1997): Climate change, loess and palaeosols: proxy measures and resolution in North China. - J. Geol. Soc., 154: 793-805, 7 Fig.; London.

Ding, Z.L., Ranov, V., Yang, S.L., Finaev, A., HaN, J.M. \& WANG, G.A. (2002): The loess record in southern Tajikistan and correlation with Chinese loess. - Earth and Planet. Sci. Lett., 200: 387-400, 7 Fig., 1 Tab.; Amsterdam. 
Dodonov, A.E. (1991): Loess of Central Asia. GeoJournal, 24: 185-194, 8 Fig.; Dordrecht. Ehlers, E. (1971): Südkaspisches Tiefland (Nordiran) und Kaspisches Meer. Beiträge zu ihrer Entwicklungsgeschichte im Jung- und Postpleistozän. - Tübinger Geogr. Stud., 44, 184 S., 54 Fig., 29 Photos; Tübingen.

FAO - Food and Agriculture Organization of the United Nations (1998): World Reference Base for soil resources. - World Soil Resources Reports, 84, 88 S.; Rome.

FAURÉ, H., WALTER, R.C. \& GRANT, D.R. (2002): The coastal oasis; ice age springs on emerged continental shelves. - Global Planet. Change, 33: 47-56.

Frechen, M. \& Dodonov, A.E. (1998): Loess chronology of the Middle and Upper Pleistocene in Tajikistan. - Geol. Rundsch., 87: 2-20, 12 Fig., 2 Tab.; Berlin.

Frechen, M., Oches, E.A. \& Kohfeld, K.E. (2003): Loess in Europe - mass accumulation rates during the Last Glacial Period. - Quat. Sci. Rev., 22: 1835-1875, 6 Fig., 2 Tab.; Oxford.

Frechen, M., Schweitzer, U. \& Zander, A. (1996): Improvements in sample preparation for the fine grain technique. - Ancient TL, 14: 15-17, 2 Fig., 1 Tab.; ClermontFerrand.

Geological Survey and Mineral ExploraTion: Geological Map 1: 100 000, Sheet No. 6763 Behshar. - Tehran.

Hatté, C., Antoine, P., Fontugne, M., Lang, A., Rousseau, D.-D. \& Zöller, L. (2001): Delta ${ }^{13} \mathrm{C}$ of loess organic matter as a potential proxy for paleoprecipitation. - Quat. Res., 55: 33-38, 3 Fig., 1 Tab.; New York.

Kehl, M., Frechen, M. \& Skowronek, A. (2005): Paleosols derived from loess and loess-like sediments in the Basin of Persepolis, Southern Iran. - Quat. Int., 140/141: 135-149, 3 Fig., 5 Tab.; Oxford.

Krolopp, E. \& SüMegi, P. (1995): Palaeoecological reconstruction of the Late
Pleistocene, based on loess malacofauna in Hungary. - GeoJournal, 36: 213-222, 3 Fig.; Dordrecht.

Lang, A., Hatté, C., Rousseau, D.D., Antoine, P., Fontugne, M., Zöller, L. \& НАмвасн, U. (2003): High-resolution chronologies for loess: comparing AMS ${ }^{14} \mathrm{C}$ and optical dating results. - Quat. Sci. Rev., 22: 953-959, 3 Fig., 2 Tab.; Amsterdam.

Lateef, A.S.A. (1988): Distribution, provenance, age and paleoclimatic record of the loess in Central North Iran. - In: EdEN, D.N. \& Furkert, R J. (Eds.): Loess - Its distribution, geology and soils. Proc. of an Internat. Symp. on Loess, New Zealand, 14.-21. Feb. 1987, 93-101, 6 Fig.; Rotterdam (Balkema).

Lazarenko, A.A. (1984): The loess of Central Asia. - In: Velichko, A. A., Wright, H. E. JR. \& BARnosky, C. W (Eds.): Late Quaternary environments of the Soviet Union. 125-131, 2 Fig., 1 Tab.; Minneapolis (Univ. Minn. Press).

Malyanov, G.A., Kasymov, S.M. \& ShermaTOV, M.S. (1987): The Uzbekistan loess, genesis and distribution. - GeoJournal, 15: 145-150, 3 Fig., 1 Tab.; Dordrecht.

Mamedov, A.V. (1997): The late PleistoceneHolocene history of the Caspian Sea. Quat. Int., 41/42: 161-166, 6 Fig.; Oxford. Middleton, N.J. (1986): A geography of dust storms in south-west Asia. - J. Climatol., 6: 183-196, 5 Fig., 2 Tab.; London.

National Iranian Oil Company (1978): Geological map of Iran at the scale of 1: 1000 000, Sheet No.1: North-West Iran. - 1 Map with explanations; Tehran.

Okhravi, R. \& Amini, A. (2001): Characteristics and provenance of the loess deposits of the Gharatikan watershed in Northeast Iran. - Global Planet. Change, 28: 11-22, 6 Fig., 3 Tab.; Amsterdam.

Oyama, M. \& Takehara, H. (1992): Revised standard soil color charts. - 13 pp, 10 Fig., 
2 Tab., 13 Plates; Japan.

Paluska, A. \& Degens, E.T. (1980): Das Quartär des Kaspischen Küstenvorlandes - Kartierung im Iran. - Mitt. Geol.-Paläont. Inst. Univ. Hamburg, 49: 61-134, 38 Fig., 3 Tab., 5 Plates; Hamburg.

Prescott, J.R. \& Hutton, J.T. (1994): Cosmic ray contributions to dose rates for luminescence and ESR dating: large depths and long-term time variations. - Radiation Measurements, 23: 497-500, 2 Fig., 2 Tab.; New York.

Rieben, E.H. (1966): Geological observations on alluvial deposits in Northern Iran. - Geological Survey of Iran, Report No. 9, 40 S., 10 Fig., 1 Plate; Tehran.

Schlichting, E., Blume, H.-P. \& Stahr, K. (1995): Bodenkundliches Praktikum. - 295 S, 46 Abb., 60 Tab.; Wien (Blackwell).

Sirocko, F., Sarnthein, M., Lange, H., ErLenkeuser, H. (1991): Atmospheric summer circulation and coastal upwelling in the Arabian Sea during the Holocene and the last glaciation. - Quat. Res., 36: 72-93, 13 Fig., 2 Tab.; New York.

Soil Survey Staff (1999): Keys to Soil Taxonomy. $-8^{\text {th }}$ Ed., 600 pp, 3 Fig.; Blacksburg, Virginia (Pocahontas Press).

Stahl, A.F.v. (1923): Zur Frage der Lößbildung. - Z. dt. geol. Ges., 74: 320-325; Stuttgart.

Stevens, L., Wright, H.E. \& Ito, E. (2001): Proposed changes in seasonality of climate during the Lateglacial and Holocene at Lake Zeribar, Iran. - The Holocene, 11: 745-755, 5 Fig., 2 Tab; London.

SWRI - Soil and Water Research Institute (2000): Soil Resources and use potentiality map of Iran (1:1 000 000). - 6 sheets; Tehran.
Thomas, D.S.G., Bateman, M.D., MehrShahi, D. \& O’Hara, S.L. (1997): Development and environmental significance of an eolian sand ramp of Last-Glacial age, Central Iran. - Quat. Res., 48: 155-161, 5 Fig., 2 Tab.; New York.

Tietze, E. (1877): Über Lössbildung und über die Bildung von Salzsteppen. - Verh. k. u. k. geol. Reichsanstalt, 15: 264-268; Berlin.

Tungsheng, L., Zhisheng, A., Baoyin, Y. \& Jiamao, H. (1985): The loess-paleosol sequence in China and climatic history. - Episodes, 8: 21-28, 8 Fig., 1 Tab., 1 Photo; Beijing.

VAN Reeuwijk, L.P., Ed. (1995): Procedures for soil analysis. -105 pp; Wageningen.

Van Zeist, W. \& Bottema, S. (1991): Late quaternary vegetation of the Near East. - Beihefte zum TAVO, Reihe A 18, 155 S., 49 Abb., 6 Tab.; Wiesbaden (Dr. Ludwig Reichert).

Wintle, A.G. \& Packman, S.C. (1988): Thermoluminescence ages for three sections in Hungary. - Quat. Sci. Rev., 7: 315-320, 2 Fig., 1 Tab.; Oxford.

Wright, J. S. (2001) "Desert" loess versus "glacial" loess: quartz silt formation, source areas and sediment pathways in the formation of loess deposits. - Geomorphology, 36: 231256, 12 Fig.; Amsterdam.

Zhou, L.P., Dodonov, A.E. \& Shackleton, N.J. (1996): Thermoluminescence dating of the Orkutsay loess section in Tashkent region, Uzbekistan, Central Asia. - Quat. Sci. Rev., 14: 721-730, 5 Fig., 3 Tab.; Oxford.

Zöller, L., Oches, E.A. \& McCoy, W.D. (1994): Towards a revised chronostratigraphy of loess in Austria with respect to key sections in the Czech Republic and in Hungary. - Quat. Geochron., 13: 465-472, 6 Fig., 4 Tab.; Oxford. 